\title{
EVALUATING A METHODOLOGY FOR ASSESSING THE STRATEGIC ALIGNMENT OF A MINING COMPANY RECRUITMENT FUNCTION
}

\author{
Authors: \\ Adelé Janse van Rensburg \\ Gerhard (Gert) Roodt
}

\section{Affiliations:}

${ }^{1}$ Department of Industrial

Psychology and People

Management, University of

Johannesburg, South Africa

Correspondence to:

Gerhard (Gert) Roodt

e-mail:

groodt@uj.ac.za

\section{Postal address:}

PO Box 524, Auckland Park 2006, South Africa

Keywords:

recruitment best practice; strategic alignment; $\mathrm{HC}$

BRidge $^{\mathrm{TM}}$; qualitative evaluation; mining industry

\section{Dates:}

Accepted: 03 Mar. 2009

Received: 26 June 2009

Published: 21 Aug. 2009

How to cite this article: Janse van Rensburg, A., \& Roodt, G. (2009). Evaluating a methodology for assessing the strategic alignment of a mining company recruitment

function. SA Journal of Human Resource Management/SA Tydskrif vir Menslikehulpbronbestuur 7(1), Art. \#201, 9 pages. DOI: 10.4102/sajhrm.v7i1.201

\section{This article is available} at:

http://www.sajhrm.co.za (c) 2009. The Authors. Licensee: OpenJournals Publishing. This work is licensed under the Creative Commons Attribution License.

\begin{abstract}
In the human capital era, the strategic importance of measurement is unmistakable. Therefore, the objective of this study was to qualitatively evaluate a methodology for assessing the strategic alignment of a recruitment function. Persons working in the recruitment best practice community of a mining company were targeted as the case study for this research. Individual (one-on-one) and focus group interviews were conducted to elicit the research data. Thematic coding was used to identify the emerging themes from the research data. The findings indicated that this methodology can be used effectively to determine the alignment of the recruitment function with the strategic objectives of the company. However, the bottom line contribution is still unclear.
\end{abstract}

\section{INTRODUCTION}

Have you ever been asked to provide a strategic report on recruitment and you just did not know where to start or what to include? After all, what exactly is meant by 'strategic' and do your standard reports on number of advertisements and recruitment costs meet these strategic requirements? According to Duggan (2004), strategic reports are easy. You just need to combine various recruitment metrics and you need to understand how the outcomes of these measures influence the overall objectives of the company. However, how do we determine what to measure out of the multitude of available metrics? The answer to this is quite simple: You need to ensure that the (recruitment) function is aligned with the strategic objectives of the company (Boudreau \& Ramstad, 2007), then measure each specific strategic objective.

If strategic reporting is this simple, why do we still struggle? Apparently, it is because the recruitment function is not aligned with the objectives of the company (Heraty \& Morley, 1998, p. 663) because we are not 'appreciating the strategic imperative of effective recruitment and selection practices'. In addition, confusion also reigns for the reason that the majority of research focused mostly on what measures are available (Armstrong, 2005; Fitz-enz, 1987; Millick, 2007) or why to measure (Becker, Huselid \& Ulrich, 2001; Darien, 2005; Hansen, 2004; Yeung, 2005) and completely neglected the part that informs us how to determine what to measure based on the objectives of the company. Research also proved that a limited number of the identified 100 best companies in America are measuring strategic impact (Davidson, 1998) because they do not know how to do it objectively (Davidson, 1998; Fitz-enz, 1987). Different works on the 'how' aspect have been published since then (Becker, Huselid \& Beatty, 2009; Becker et al., 2001; Huselid, Becker \& Beatty, 2005).

The increasing demand for more strategic information underlines the need for research to provide more than just a list of measurements or reasons why to measure. We need to know how to determine what to measure and this study will therefore aim to qualitatively evaluate the methodology of the Human Capital Bridge (HC BRidge ${ }^{\mathrm{TM}}$ ) framework of Boudreau and Ramstad (2007).

The main contribution of this study is to qualitatively evaluate the methodology of the HC BRidge ${ }^{\mathrm{TM}}$ framework. This framework provides a methodology for establishing alignment between the operational objectives of the recruitment function (as an exemplary human resources (HR) function) and the strategic objectives of the company.

The benefits of the study are twofold:

- It evaluates the HC BRidge ${ }^{\mathrm{TM}}$ framework or tool to assist in identifying and developing strategic measures (Boudreau \& Ramstad, 2007).

- Although the nature of a qualitative case study within the mining industry might hinder the generalisation of the results, the cross-functionality of the HC BRidge ${ }^{\mathrm{TM}}$ framework methodology has some relevance outside the mining industry.

This article is divided into four parts. Firstly, an overview of literature relating to a framework to determine strategic alignment, strategic measurements found in the literature as well as the importance of recruitment metrics will be provided. This is followed by a detailed description of the research design, including the approach and the research method used. The third section covers the findings of the study. The article concludes with a discussion of the findings, including possible limitations of the study and suggestions for future research. The literature review will be discussed in the next section.

\section{LITERATURE REVIEW}

The literature review consists of three sections. Section one describes the HC BRidge ${ }^{\mathrm{TM}}$ methodology (how to measure) that is used to determine the alignment of the objectives of the recruitment function with those of the company. In the second section (what to measure), the HC BRidge ${ }^{\mathrm{TM}}$ framework is applied to categorise the various metrics available into different groupings and according to literature sources. The last section (why measure) provides an overview of the importance of measuring the impact of a function on the bottom line of the company. 


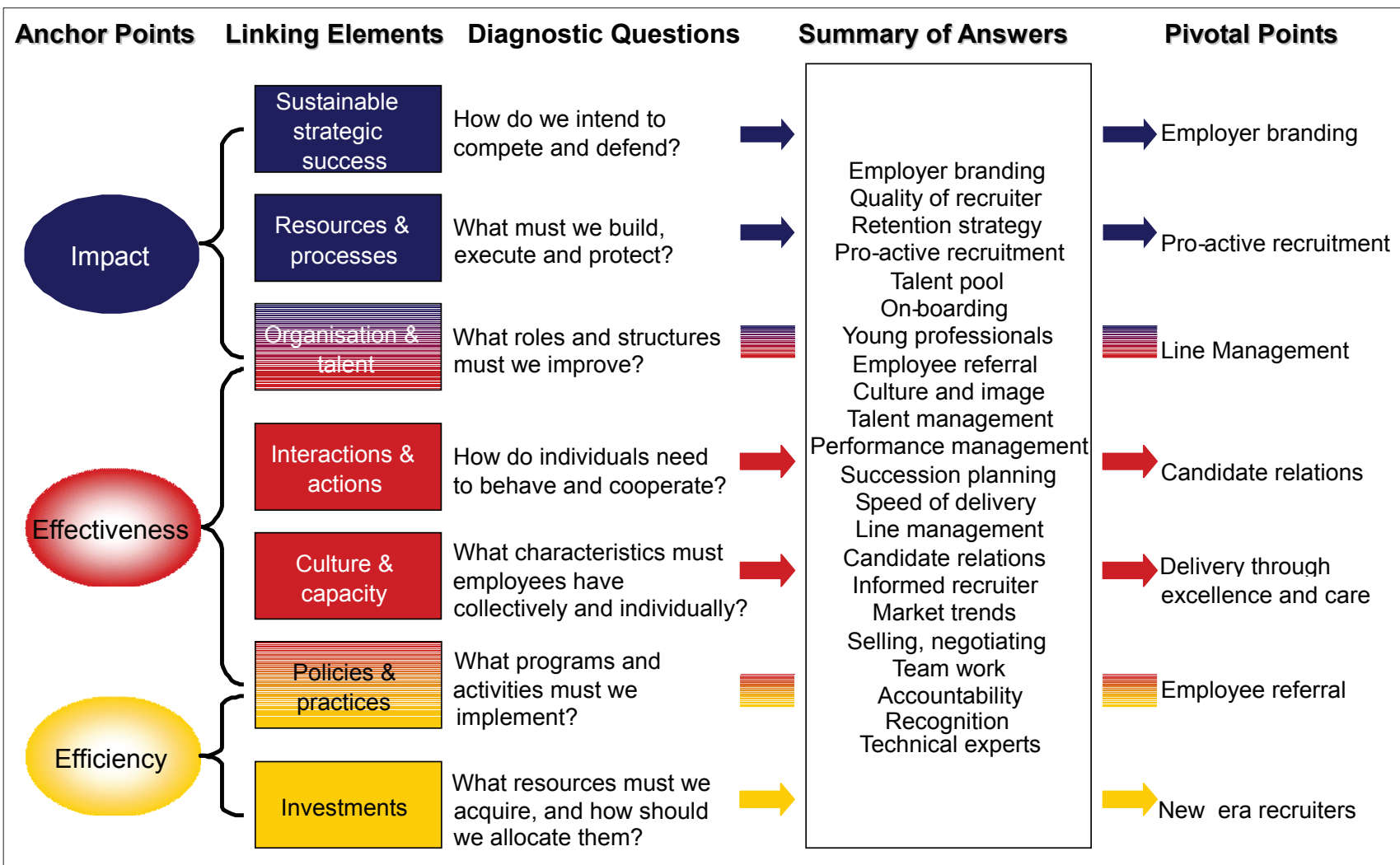

\section{The HC BRidge ${ }^{\mathrm{TM}}$ framework}

As previously mentioned, nonalignment between the objectives of a function and the strategy of a company is a common problem (Becker et al., 2001; Heraty \& Morley, 1998; Roberts, 1994). Boudreau and Ramstad believe that their decision science model will be able to solve this problem. In their model name, the HC BRidge $^{\mathrm{TM}}$, 'HC' stands for human capital and the capitalised 'BR' indicates the authors' last names, Boudreau and Ramstad (Moore, 2007). The 'bridge' component relates to three anchor points, impact, effectiveness and efficiency, that according to the authors form the basis of all decision making and related strategic measures. This sophisticated toolset will assist companies to translate employees' actions into financial value (Boudreau \& Ramstad, 2007). In other words, the framework assists companies to measure the outcome of a function in terms of its contribution to the overall objectives of the company.

Figure 1 below shows an overview of the HC BRidge ${ }^{\mathrm{TM}}$ framework (Boudreau \& Ramstad, 2007, p. 68). It portrays a framework based on three anchor points, impact, effectiveness and efficiency, that are further described by several linking elements. Through these linking elements, each anchor point represents some impact on the business:

- Efficiency represents how investments impact policies and procedures.

- Effectiveness describes how policies and practices influence the organisation.

- Impact illustrates how the employees affect sustainable strategic success.

The reason for using this framework is to transform the HR (recruitment) field from merely being strategy implementers to a function that drives an organisation strategically and has major impacts (Moore, 2007)

For each linking element several diagnostic questions have been developed to stimulate creative thinking, to 'defy conventional wisdom' and to uncover 'opportunities for significant and unique competitive advantage' (Boudreau \& Ramstad, 2007, p. 49).

The model works on the premise that every function or organisation should include all three anchor points to ensure strategic alignment. In answering the diagnostic questions for each linking element, the function or organisation should be able to identify those elements that are most critical to the success of the organisation. In order to identify these critical success factors, it is necessary to create a clear distinction between what is important ${ }^{1}$ and what is pivotal ${ }^{2}$ (Boudreau \& Ramstad, 2007), as pivotal elements are those that an organisation or function cannot do without.

\section{What to measure: Selecting strategic relevant metrics}

The previous section provided an overview of the important role of the HC BRidge ${ }^{\mathrm{TM}}$ framework in strategy alignment and the development of strategic measures. This section will summarise the recruitment measures found in the literature. Millick (2007) identified the following top three recruitment measures:

- cost-to-hire

- time-to-fill

- number of requisitions filled

It is clear that the top three recruitment measures as identified by Millick (2007) are looking at historical activities only. Those measurements that deal with forward looking for planning and decision-making aspects to inform strategic support (Flamholtz, 2005) were excluded. From the literature, it is clear that truly strategic measures include 'cost control' and 'value creation' (Becker et al., 2001, p. 23). In the terminology of the

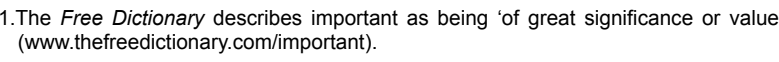

1.The Free Dictionary describes important as being 'of great significance or value' (www.thefreedictionary.com/important)

2.Pivotal is described as 'of crucial importance' (www.thefreedictionary.com/pivotal). 
TABLE 1

Summary of typical recruitment metrics

\begin{tabular}{|c|c|c|c|c|c|}
\hline \multirow[b]{2}{*}{ DESCRIPTION } & \multirow[b]{2}{*}{ MEASURE } & \multirow[b]{2}{*}{ LITERATURE SOURCE } & \multicolumn{3}{|c|}{ HC BRIDGE ${ }^{\mathrm{TM}}$ - THREE ANCHOR POINTS } \\
\hline & & & EFFICIENCY & EFFECTIVENESS & IMPACT \\
\hline \multirow[t]{5}{*}{ Cost control } & Cost-to-hire & Fitz-enz \& Davison, 2002; Hansen, 2005; Millick, 2007 & $\mathrm{x}$ & & \\
\hline & Advertising costs & Smith \& Graves, 2002 & & & \\
\hline & Source cost per hire & Fitz-enz \& Davison, 2002; Smith \& Graves, 2002 & $x$ & & \\
\hline & Interview cost & Fitz-enz \& Davison, 2002 & $\mathrm{x}$ & & \\
\hline & & & $x$ & & \\
\hline Time control & Time-to-fill & Fitz-enz \& Davison, 2002; Hansen, 2005; Millick, 2007 & $x$ & & \\
\hline \multirow[t]{7}{*}{ Volume control } & Number of requisitions filled & Millick, 2007 & $x$ & $x$ & \\
\hline & Referral rate & Fitz-enz \& Davison, 2002 & & $x$ & \\
\hline & Job posting response rate & Fitz-enz \& Davison, 2002 & $x$ & & \\
\hline & Talent management & Yeung, 2005 & & & $x$ \\
\hline & On-boarding & Yeung, 2005 & & & $x$ \\
\hline & Turnover & Fitz-enz \& Davison, 2002 & & $\mathrm{x}$ & \\
\hline & New employee productivity & Smith \& Graves, 2002 & & & $\mathrm{x}$ \\
\hline \multirow[t]{5}{*}{ Value creation } & Hire ratio & Fitz-enz \& Davison, 2002 & & $x$ & \\
\hline & Offer acceptance rate & Fitz-enz \& Davison, 2002 & & $x$ & \\
\hline & Quality of hire & Fitz-enz \& Davison, 2002; Hansen, 2005 & & $x$ & \\
\hline & Succession planning ratio & Hansen, 2005 & & $x$ & \\
\hline & Retention rate & Hansen, 2005; Rowald \& Mönninghoff, 2005 & & $x$ & \\
\hline
\end{tabular}

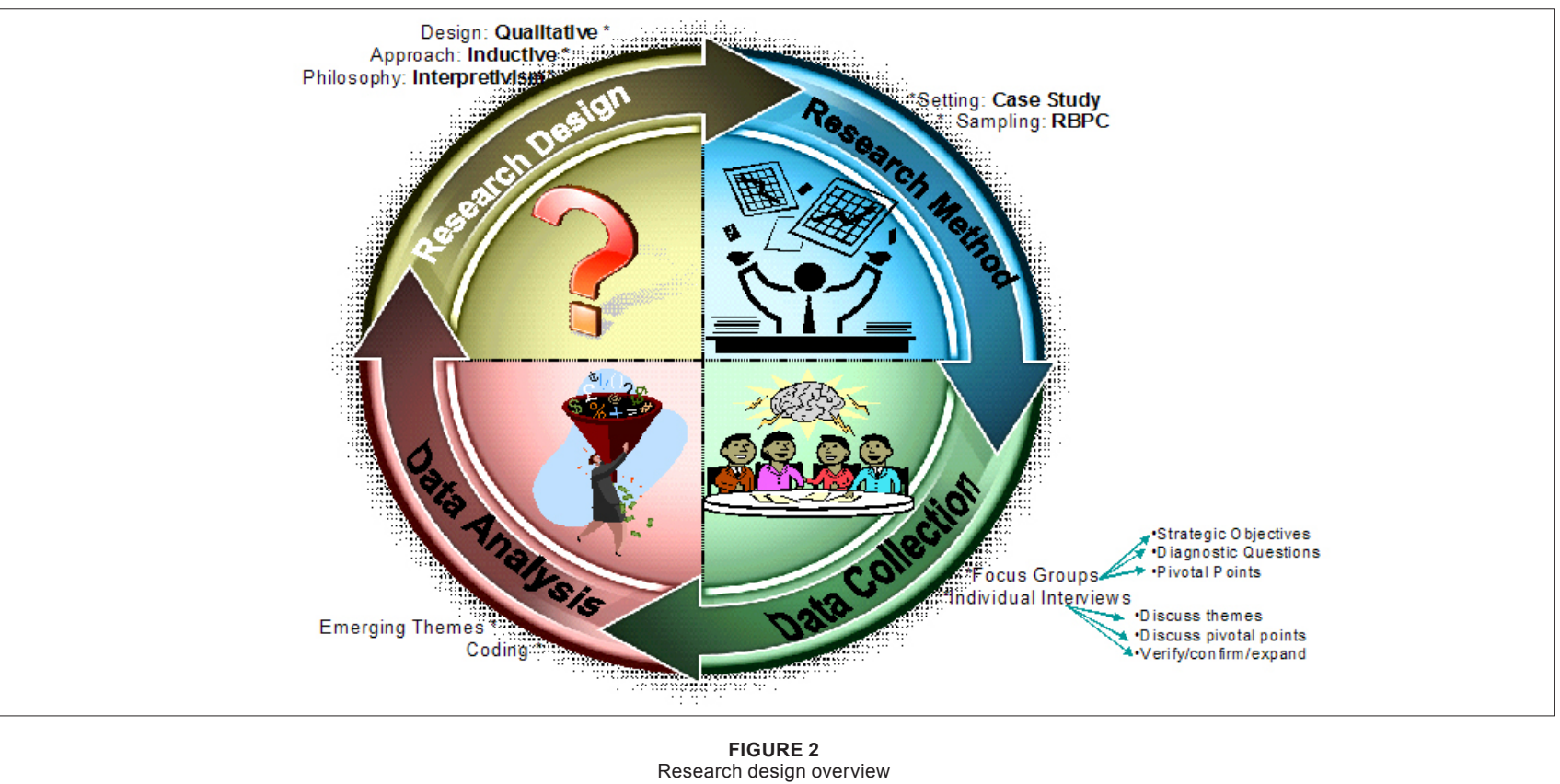

HC BRidge ${ }^{\mathrm{TM}}$, it includes efficiency (cost, time and volume), effectiveness (quality) and impact (customer satisfaction and value) measurements (Boudreau, Dunford \& Ramstad, 2000).

Table 1 provides an overview of different measures found in the literature. It has been categorised into the three anchor points of Boudreau and Ramstad (2007) and from there further grouped into cost control, time control, volume control and value creation.

From Table 1, it is clear that strategic recruitment metrics do exist as the identified metrics cover all aspects from cost control to value creation as well as efficiency, effectiveness and impact. However, it is believed that due to the high complexity of the recruitment function, it is difficult to integrate the measures to indicate strategic impact (Rowald \& Mönninghoff, 2005). It should then be no surprise to see that the use of these measures in isolation fail to portray the intelligence needed to understand, evaluate and make strategic decisions about the function.
To conclude, the identified measures and their failure to prove strategic success verify the importance of utilising a decisionbased model to establish and prove strategic alignment. In the next section why strategic measures and alignment are important will be explained.

\section{Why measure: Assessing progress towards strategic goal achievement}

It is a well-known fact that the HR environment has undergone dramatic change over the last couple of years (Becker et al., 2001; Boudreau \& Ramstad, 2007; Fitz-enz \& Davison, 2002; Losey, Meisinger \& Ulrich, 2005) and had to move from being anchored in the behavioural field to a field 'rooted in measurement and analytical tools' (Flamholtz, 2005, p. 268). Subsequently, the need for an integrated recruitment measurement system to inform business decisions has become a driving force in the strategic planning of leading companies. Managers are expecting hard data but 'both practice and research shows that [recruitment] measurement and evaluation is hindered by the absence of a decision-based approach' (Boudreau \& Ramstad, 2004, p. 5). 
This might be why we still measure ourselves using only the traditional measures that focus primarily on efficiency and in some rare instances also on effectiveness.

Based on the HC BRidge ${ }^{\mathrm{TM}}$ framework, we need to identify the pivotal points in recruitment in order to prove strategy contribution. However, identifying the pivotal points might be problematic as Becker et al. (2001) state that companies do not know how to determine what is important if you look at what they are measuring. It is believed that this might be happening as a result of the dramatic shift in the role of HR whereby managers are increasingly requested to prove how they create value for the company instead of how to improve decisions. In addition, Ellig (2005, p.127) states, 'The successful HR business partner is one who knows not only the cost of action but also the value added, for if there is no value added, why should there be a cost?'.

Therefore, Ellig (2005) believes that the most important transition to make is the move from compliance to services and ultimately to decisions. Furthermore, recruitment needs to move away from its focus on the day-to-day transactional activities as this is the reason why HR (and recruitment) missed its seat at the boardroom table (Darien, 2005). The challenge therefore remains to determine whether the HC BRidge ${ }^{\mathrm{TM}}$ framework can be used to evaluate whether an HR function (such as recruitment) is aligned with the strategic business objectives. Consequently, in order for recruitment to be acknowledged as an asset and not a cost centre, the function needs to do a better job at quantifying its output. The quantified output is usually in the form of measurements. It is these measurements that provide proof of the performance of the function as well as guide strategy implementation (Becker et al., 2001).

\section{RESEARCH DESIGN}

Terre Blanche and Durrheim (1999) describe the research design as a framework that directs the flow of the research from start to finish. Details of the research design and reasons why the specific design was chosen will be explained based on the research design overview depicted in Figure 2. Firstly, information will be provided on the research design, approach and philosophy. Thereafter, the research method will provide information on the chosen setting and sampling for the study whereafter the data collection methods used and how the data were analysed will be explained.

The whole research design should be read within the parameters of a qualitative research design because the data consisted of words and observations and excluded the assigning of numerical codes as is typically seen with quantitative studies. Strauss and Corbin (as cited in Neill, 2006, n.p.) define qualitative research as 'any kind of research that produces findings not arrived at by means of statistical procedures or other means of quantification'.

\section{Research approach}

True to a qualitative and interpretivist study, the qualitative approach used was inductive. Saunders, Lewis and Thornhill (2003) explain that the purpose of the inductive approach is to gain insight into what is happening in order to understand the problem better.

\section{Research philosophy}

Amongst the qualitative research philosophies (also called paradigms), interpretivism seemed to be most appropriate for this study as it focuses on human experiences within a specific context (Terre Blanche \& Durrheim, 1999). Through the utilisation of the diagnostic questions of the HC BRidge ${ }^{\mathrm{TM}}$ framework, the opinions and understanding of individuals were used to evaluate the suitability of this methodology to assess the alignment between the recruitment strategy and the company strategy. Interpretivism as the guiding research philosophy in this study is explicated below in terms of its underlying ontological and epistemological assumptions.

\section{Ontology}

'Ontology specifies the nature of reality that is to be studied' (Terre Blanche \& Durrheim, 1999, p. 6): in other words, it is 'the study of being' (Mayer, 2008, p. 24). Ontology ask the questions 'what is there to know?' and 'what assumptions can be made about the world' (Willig, 2003, p. 13). Therefore, the interpretivism approach allowed us to study the recruitment alignment using the subjective experiences of the various participants.

\section{Epistemology}

The unique opinions and experiences of the recruitment best practice community were critical to the study. Terre Blanche and Durrheim (1999, p. 6) call this 'epistemology' because it reflects 'the nature of the relationship between the researcher and what can be known'. The epistemological stance of the research was therefore interpretivism as it studies the 'subjective meanings motivating people's actions in order to be able to understand (Saunders et al., 2003, p. 84).

\section{Research strategy}

A case study was used as the research strategy in this study Bogdan and Biklen (1998, p. 54) define a case study as 'a detailed examination of one setting, or a single subject' - in this study the recruitment best practice community (RBPC) of the company. The RBPC enabled us to 'gain a rich understanding of the contex of the research and the process being enacted' (Saunders et al., 2003, p. 93).

\section{Research method}

The research method will be discussed in terms of the following headings: Research setting and entrée, sampling, data collection and data analysis.

\section{Research setting and entrée}

The case study was conducted on the RBPC in this large and successful mining and resources company in South Africa where the first author and field researcher in this study was also employed. Terre Blanche and Durrheim (1999) call this researcher role a participant-observer role.

\section{Sampling}

For the purpose of this study, employees with the same type of experience and knowledge (Terre Blanche \& Durrheim, 1999) were chosen for the focus groups. In the company, these employees are part of the RBPC of which 15 members indicated a willingness to take part in the study. The RBPC consists of employees ranging from specialists to line managers, including specialistrecruiters, HRmanagers, psychometrists, HRgeneralists and administrators. Terre Blanche and Durrheim (1999) call this accessibility of the community and their related willingness to participate convenience or opportunistic sampling.

In addition, purposive sampling (Bogdan \& Biklen, 1998; Willig, 2003) was utilised to collect data since participants for the interviews were selected based on their knowledge of recruitment as well as strategic alignment. Furthermore, the participants for both the focus groups and interviews were well represented across the different managerial levels within the company. The members of the RBPC 'have a stake' in the outcome of the research as it will enable them to implement the research results at their respective workplaces (Willig, 2003, p. 30).

\section{Data collection}

Interpretive researchers study situations in their natural setting (Willig, 2003). In this case, the natural setting involved the RBPC. The focus groups with the RBPC were difficult to schedule due to the ever-changing diaries of the participants. However, since the focus groups were the main source of data, patience was the order of the day. In the focus groups, participants were encouraged to share their experiences and comment on 
one another's contributions, but most of all challenge each other's statements (Kitzinger, 1995). Through the utilisation of the diagnostic questions of the HC BRidge ${ }^{\mathrm{TM}}$ framework, the suitability of this methodology for assessing the strategic alignment of the recruitment function with the objectives of the company was evaluated. Data that were used to evaluate the framework were obtained from company records and related to the objectives of the company and the recruitment function. Table 2 provides an overview of these objectives.

The diagnostic interview questions of the HC BRidge ${ }^{\mathrm{TM}}$ framework elicited data on the experiences and opinions of the recruiters with regard to the potential of the framework to assess the strategic alignment of the recruitment function with the objectives of the company. The sharing of experiences was encouraged around the diagnostic questions of the HC BRidge $^{\mathrm{TM}}$ framework in order to determine the pivotal points in recruitment. The discussions resulted in the permutation of experiences (opinions and understanding) of individuals regarding the strategic input of the Recruitment Department. Rich data were gathered that provided information on both subjective and intersubjective experiences as shared by the RBPC.

The researchers' secondary data source was individual interviews with key stakeholders. The purpose of the individual interviews was to confirm, verify and expand on the data gathered during the focus groups. Brief overviews of the emerging themes as derived from the focus groups were discussed during the informal and semistructured interviews with the stakeholders. The semistructured interview format increased the need for more cross-checking of the emerging themes which posed more challenges during the coding process. It also ensured that enough information was verified to confirm the emerging themes.

This highly successful mining company provided the perfect backdrop to evaluate the usefulness of the HC BRidge ${ }^{\mathrm{TM}}$ framework as a methodology to assess the alignment of objectives between recruitment and the company. Through the various focus group discussions and individual interviews, data were gathered and grouped into the three recruitment objectives. The members of the RBPC (and later the individual interviewees) further identified pivotal points for each objective from the data based on the answers to the diagnostic questions provided by the HC BRidge ${ }^{\mathrm{TM}}$ framework.

\section{Data analysis}

Table 3 provides an overview of the data analysis process followed that is briefly explained below. Field notes of the focus groups and interviews were studied. Through the inductive research approach patterns (emerging themes) were identified by means of 'thematic coding' (Bowen, 2005, p. 217). Thematic coding is a process whereby the data is grouped into different themes or categories in order to reduce the data into 'meaningful groupings' (Grbich, 2007, p. 32; Willig, 2003). The initial themes were based on 'certain words, phrases....and events' that were repeated and stood out (Bogdan \& Biklen, 1998, p. 171). This process, which took place throughout the whole data analysis process, can also be referred to as preliminary data analysis as it is a

simple process of checking and tracking the data to see what is coming out of them, identifying areas which requires follow-up and actively questioning where the information collected is leading.

(Grbich, 2007, p. 25)

From there, data were coded through the use of the additional information provided through the one-on-one interviews. Coding is a process whereby data is subdivided into different clusters of information in relation to a specific theme.

During the semistructured interviews, confirmation-type questions were asked related to the pivotal points as identified by the members of the focus groups. These questions sometimes functioned as 'triggers' that encouraged the participant to talk about their experiences and opinions (Willig, 2003, p. 24). The interview agenda consisted of a number of open-ended questions about the identified pivotal points as well as the views of the interviewees on the strategic alignment (or lack thereof) of the recruitment function. In addition, the interviewees were prompted to provide answers in terms of how they think the pivotal points can be used to address the specific recruitment objective. In order to ensure that the comments and opinions of the interviewees were understood correctly, the interviewees were requested to provide specific examples.

Weston et al. (2001, p. 382) mention that the process of coding can be influenced by various factors:

- The researcher's view of the data and the 'meaning attributed to it'

- The researcher's interpretation of the data.

In addition, it is also believed that the researcher's work background in the recruitment function also may influence the coding process.

Through the inductive research approach, the following steps as identified by Thomas (2003) were taken:

- Establishing emerging themes

- Creating obvious links between the data gathered and the research objectives

- Developing a finding.

The preliminary data were continuously analysed throughout the process in order to find common patterns and themes (Grbich, 2007; Willig, 2003). As previously explained, each recruitment objective was critically explored using the diagnostic questions of the HC BRidge ${ }^{\mathrm{TM}}$ framework. Huselid and Becker (2005, p. $280)$ define this process as 'analytical literacy'. This implies that a new set of questions was asked about recruitment to facilitate the process whereby the participants of the RBPC identified the pivotal points through answering the diagnostic questions as described in the HC BRidge ${ }^{\mathrm{TM}}$ framework.

\section{FINDINGS}

The HC BRidge ${ }^{\mathrm{TM}}$ framework was evaluated as a methodology to assess whether alignment exists between the three objectives of recruitment and the seven objectives of the company.

Table 2 provides an overview of the objectives of the company and recruitment and at first glance no clear or obvious alignment is found. This unclear alignment might be the reason why the function finds it difficult to provide strategic recruitment reports. After all, if you do not see the big picture, how can you measure your progress towards reaching it? It is important to mention at this stage that the unclear alignment does not necessarily mean that there is no alignment. It merely highlights the problem towards nonstrategic reporting and decision making.

Tables 4 to 6 below provide an overview of the outcome of the various focus groups and individual interviews. The members of the RBPC identified pivotal points for each recruitment objective through several diagnostic questions from the HC BRidge ${ }^{\mathrm{TM}}$ framework as depicted in Figure 1. Furthermore, the emerging evaluative themes and related exemplary quotes provide the qualitative evaluation of the applied methodology.

An evaluative interpretation of each of the three recruitment objectives follows below:

Objective 1: Increase attraction through the utilisation of a marketing and branding campaign to position the company as an employer of choice

One of the emerging themes identified in Table 4 indicates that the recruitment function needs to develop and market an employee value proposition in order to gain a competitive advantage. This theme is aligned with the first objective of the company: becoming the leading global mining company of choice. A 
proper marketing and branding strategy presupposes a value creation through networking and related relationship building with both internal and external customers and stakeholders.

The second emerging theme indicates that the value proposition will only be successful if line managers also buy into the process.

The pivotal points identified relate to the overall image of the function through its creative use of processes and building of candidate relations. This theme also indicates that the recruitment function will not be able to fulfil this objective on its own as it relates to other departments such as remuneration and benefits, work conditions and talent management. This insight will contribute greatly towards better decision making as the interfaces and interdependencies with other departments are now clearly highlighted. In addition, the pivotal points pick up the importance of measuring the effectiveness of the function in delivering the employee value proposition.

\section{Objective 2: Increase engagement of employees through appropriate retention and on-boarding strategies}

Table 5 highlights the third emerging theme that indicates the need for the development of postrecruitment procedures such as retention and on-boarding strategies. It is hoped that the implementation of these strategies will increase attraction and retention, which will ultimately enhance the company's image as employer of choice. Evidently, the second recruitment objective is also $100 \%$ aligned with the first objective of the company.

\section{Objective 3: Re-engineer the recruitment process to eliminate red tape}

The pivotal points for the third recruitment objective (in Table 6 ) identified two key constraints: reactive recruiters and a reactive recruitment process. Therefore, in order for the function to evolve into strategic alignment, this will need to be addressed. One possible solution (although definitely not the only one) identified the need for new role descriptions as the current role descriptions only highlight the standard day-to-day actions of recruiters and do not reflect the proactive components and the related link to the overall strategy.

In addition, the pivotal points indicated that it is no longer acceptable for a recruiter to administer a job applicant from one stage to the next (reactive recruitment process). It is now of paramount importance to co-ordinate, integrate and facilitate the job applicant into the company culture throughout the whole recruitment process.

In conclusion, the study found that all three pivotal points have been identified for two of the three recruitment objectives. According to the HC BRidge ${ }^{\mathrm{TM}}$ framework, the implication is therefore that the correct measurements for each pivotal point will prove the impact of the function on the bottom line of the company. However, of great concern is the fact that the recruitment objectives are aligned with only two of the seven company objectives. It is clear that a gap exists between what recruitment is focusing on and what the company expects of the function.

\section{DISCUSSION}

The purpose of this study was to qualitatively evaluate the HC BRidge $^{\mathrm{TM}}$ framework (Boudreau \& Ramstad, 2007) methodology to assess the degree of alignment between the objectives of the recruitment department and the company's strategic objectives. The study indicates that this methodology can be effectively applied to determine the alignment between operational and company strategic objectives.

\begin{tabular}{|c|c|c|c|}
\hline \multicolumn{4}{|c|}{$\begin{array}{l}\text { TABLE } 2 \\
\text { Overview of the company and recruitment objectives }\end{array}$} \\
\hline \multicolumn{2}{|c|}{ COMPANY OBJECTIVES } & \multicolumn{2}{|c|}{ RECRUITMENT OBJECTIVES } \\
\hline 1. & Become the leading global mining company of choice & 1. & Increase attraction through the utilisation of a \\
\hline 2. & Employ the best talent in the industry & & marketing and branding campaign to position the \\
\hline 3. & Set the highest standards for safety in the industry & & company as an employer of choice \\
\hline 4. & Deliver consistently superior value for our shareholders by outperforming our peers & 2. & Increase engagement of employees through \\
\hline 5. & Own and operate a world-class asset portfolio that is cost advantaged and in the most attractive market & & appropriate retention and on-boarding strategies \\
\hline & segments & 3. & Re-engineer the recruitment process to eliminate \\
\hline 6. & Capture the best growth opportunities in the world & & red tape \\
\hline 7. & Be considered the 'preferred partner' of governments and communities for ongoing operations and new & & \\
\hline
\end{tabular}

TABLE 3

Overview of the data analysis

\begin{tabular}{|c|c|c|}
\hline DATA UTILISED & PARTICIPANTS & DATA ANALYSIS PROCESS FOLLOWED \\
\hline $\begin{array}{l}\text { - Diagnostic questions from HC BRidge }{ }^{\mathrm{TM}} \text { framework } \\
\text { - Strategic objectives of the company } \\
\text { - Strategic objectives of the recruitment function }\end{array}$ & Focus groups & $\begin{array}{l}\text { - Collected field notes } \\
\text { - Answered the diagnostic questions for each recruitment objective } \\
\text { objective in relation to the three anchor points } \\
\text { - The definitions of important vs. pivotal were applied in order to } \\
\text { determine the pivotal points }\end{array}$ \\
\hline $\begin{array}{l}\text { - Identified pivotal points for each anchor point } \\
\text { - Strategic objectives of the recruitment function }\end{array}$ & Individual interviews & $\begin{array}{l}\text { - Participants were briefed on the objectives of the research and } \\
\text { requested to evaluate and validate the data (pivotal points) flowing } \\
\text { from the focus groups } \\
\text { Once the data were validated, participants were prompted to provide } \\
\text { answers in terms of how they believe these pivotal points can be } \\
\text { addressed } \\
\text { The answers to these questions were also reduced into meaningful } \\
\text { groupings in order to establish the emerging themes. } \\
\text { Each emerging theme related to an action (how) to assist in reaching } \\
\text { that particular recruitment objective }\end{array}$ \\
\hline - Field notes & $\begin{array}{l}\text { Focus groups, } \\
\text { individual interviews }\end{array}$ & $\begin{array}{l}\text { Phrases from the participants were highlighted in the exemplary } \\
\text { quotes to indicate the individual contributions in terms of the pivotal } \\
\text { points and related emerging themes }\end{array}$ \\
\hline
\end{tabular}


TABLE 4

Recruitment objective 1

\begin{tabular}{|c|c|c|c|}
\hline RECRUITMENT OBJECTIVE & PIVOTAL POINTS & EMERGING THEMES & EXEMPLARY QUOTES \\
\hline $\begin{array}{l}\text { Increase attraction through the utilisation } \\
\text { of a marketing and branding campaign } \\
\text { to position the company as an employer } \\
\text { of choice }\end{array}$ & $\begin{array}{l}\text { Impact anchor point } \\
\text { - } \quad \text { Attract scarce skills proactively before } \\
\text { other companies } \\
\text { - } \quad \text { Flexible practices } \\
\text { - } \quad \text { Require new programs, i.e. employee } \\
\text { referral } \\
\text { - Communicate the employee value } \\
\text { proposition of the company } \\
\text { - } \quad \text { Candidate relations } \\
\text { Effectiveness anchor point } \\
\text { - } \text { Acquire talented individuals } \\
\text { - Create value } \\
\text { - Best remuneration packages } \\
\text { Efficiency anchor point } \\
\text { - No efficiency anchor points were } \\
\text { identified }\end{array}$ & $\begin{array}{l}\text { 1. Competitive advantage will be } \\
\text { obtained through marketing } \\
\text { the company's employee value } \\
\text { proposition } \\
\text { 2. Line manager education and buy- } \\
\text { in will enable effective candidate } \\
\text { relations }\end{array}$ & $\begin{array}{l}\text { 'Managers of the future are more } \\
\text { employee focused' } \\
\text { 'The goal of recruitment is to establish a } \\
\text { large database of competent and talented } \\
\text { individuals willing to work in our company' } \\
\text { 'We need to work together to promote the } \\
\text { joining of the different operations into one } \\
\text { leading global company' }\end{array}$ \\
\hline
\end{tabular}

TABLE 5

Recruitment objective 2

\begin{tabular}{|c|c|c|c|}
\hline RECRUITMENT OBJECTIVE & PIVOTAL POINTS & EMERGING THEMES & EXEMPLARY QUOTES \\
\hline \multirow[t]{6}{*}{$\begin{array}{l}\text { Increase engagement of employees } \\
\text { through appropriate retention and on- } \\
\text { boarding strategies }\end{array}$} & $\begin{array}{l}\text { Impact anchor point } \\
\text { Employer branding } \\
\text { - Retain scarce skills through } \\
\text { addressing both hygiene and }\end{array}$ & $\begin{array}{l}\text { 1. Importance of line management buy- } \\
\text { in to make the process a success } \\
\text { 2. Postrecruitment procedures needed }\end{array}$ & \multirow{6}{*}{$\begin{array}{l}\text { 'The first six months of employment } \\
\text { determines whether or not employees will } \\
\text { stay with the company' } \\
\text { 'Professional job-hoppers necessitate } \\
\text { the implementation of recognition } \\
\text { programmes' } \\
\text { 'Use the talent that you recruit to gain a } \\
\text { competitive edge' }\end{array}$} \\
\hline & motivation factors & & \\
\hline & $\begin{array}{l}\text { Effectiveness anchor point } \\
\text { - Leadership engagement and buy-in }\end{array}$ & & \\
\hline & $\begin{array}{l}\text { - Line management education } \\
\text { - Culture and image } \\
\text { Alignment between supporting }\end{array}$ & & \\
\hline & $\begin{array}{ll} & \text { policies and procedures } \\
\text { - } & \text { On-boarding strategy } \\
\text { Internal marketing and branding } \\
\text { campaign }\end{array}$ & & \\
\hline & $\begin{array}{l}\text { Efficiency anchor point } \\
\text { - Performance management } \\
\text { - Recognition }\end{array}$ & & \\
\hline
\end{tabular}

TABLE 6

Recruitment objective 3

\begin{tabular}{|c|c|c|c|}
\hline RECRUITMENT OBJECTIVE & PIVOTAL POINTS & EMERGING THEMES & EXEMPLARY QUOTES \\
\hline $\begin{array}{l}\text { Re-engineer the recruitment process to } \\
\text { eliminate red tape }\end{array}$ & $\begin{array}{l}\text { Impact anchor point } \\
\text { - } \quad \text { Reandidate relations } \\
\text { Effectiveness anchor point } \\
\text { - Include selection criteria based on } \\
\text { - } \quad \text { Best practices } \\
\text { - Reactive recruitment process } \\
\text { - New era recruiters needed } \\
\text { Efficiency anchor point } \\
\text { - Speed of delivery }\end{array}$ & $\begin{array}{l}\text { 1. New role descriptions required for } \\
\text { proactive component of recruitment } \\
\text { 2. Selection process to be broadened to } \\
\text { include safety criteria }\end{array}$ & $\begin{array}{l}\text { 'Inappropriate processes leads to } \\
\text { inappropriate appointments which all } \\
\text { contributes towards mediocrity' }\end{array}$ \\
\hline
\end{tabular}

The findings of the study reveal that both the first and second recruitment objectives are 100\% aligned with the first strategic objective of the company. However, the specific metrics to assess the degree of strategic support are absent. Although the strategy alignment is limited (or rather focused on one area), the overall picture seems to incorporate all the recruitment strategy components as identified by Van Schalkwijk (2008):

- Importance of a unique employee value proposition (first recruitment objective).

- Competitive reward systems inclusive of both hygiene and motivation factors (second recruitment objective).
- Opportunity for growth in skills (third recruitment objective) whereby the reactive recruiters will be provided with the necessary training and exposure to acquire competencies related to the proactive side of recruitment.

In addition, the findings indicate no direct alignment between the third recruitment objective and any other objective of the company. However, it does relate to the efficiency pivotal point as the elimination of red tape should ultimately decrease cost and time (Boudreau et al., 2000). Furthermore, Boudreau and Ramstad (2007) conclude that this type of strategy, although beneficial, does not have any strategic value. Figure 3 indicates 


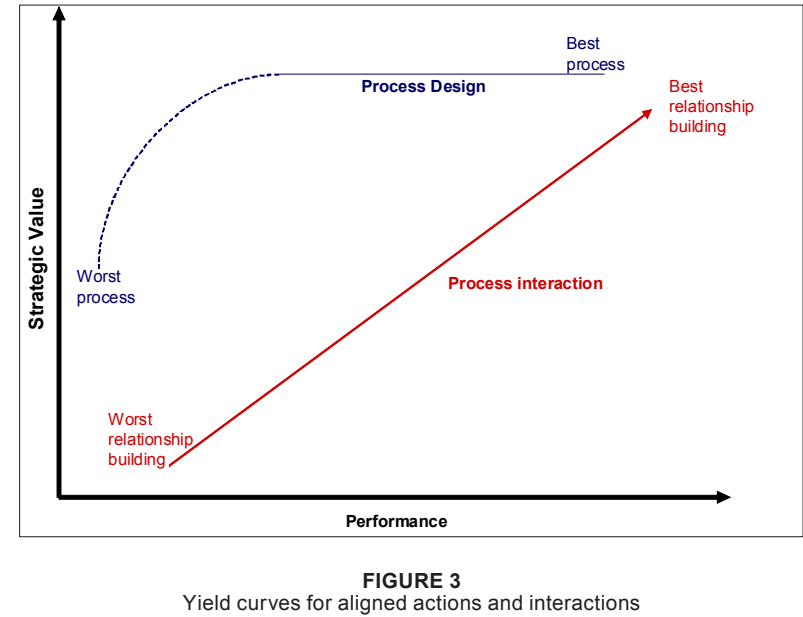

that although a process redesign will increase the performance, the strategic value remains static. The focus should rather be on a change in the process interaction as this will exponentially increase both the performance as well as the strategic value (Boudreau \& Ramstad, 2007, p. 123).

Through the use of the HC BRidge ${ }^{\mathrm{TM}}$ framework, it became quite evident that the solution to a problem is not necessarily just the opposite of the problem. During the discussion of objective three, the answer to the diagnostic question of "where would improvements in [recruitment] make the biggest difference...?' (Boudreau \& Ramstad, 2007, p. 53) led the focus groups in a different direction. The first response to the question was the appointment of proactive recruiters but it was found that proactive recruiters will not necessarily solve the process-related problems and that they will rather be solved by the buy-in and commitment of the line managers. Christensen (2006) confirms this notion and states that the importance of line managers is often overlooked. They need to get involved in what they deem as people issues. This process of not identifying just the opposite of a problem but the true solution also relates to systemic theory of solving or dissolving problems (Dostal, Cloete \& Jaros, 2005). According to systems thinking, solving a problem means that the faulty part is fixed (i.e. appointment of proactive recruiters), whereas dissolving the problem implies 'changing the functioning of a system in such a way that the problem is not reproduced, but falls away', in other words, educating line managers (Dostal et al., 2005, p. 425).

Furthermore, the literature also supports the need for new role descriptions as identified in one of the emerging themes. Boudreau and Ramstad (2007, p. 129) state that 'measuring talent decision science will undoubtedly mean more pressure for flexibility in traditional job descriptions'. New role descriptions to incorporate the proactive recruitment component together with retention and on-boarding will definitely contribute towards strategic alignment.

An unexpected finding was that the literature reveals that the current identified recruitment metrics are in fact strategic. It seems as if the problem with them relates more to the lack of integration (Rowald \& Mönninghoff, 2005) and failure to use a decision based model (Boudreau \& Ramstad, 2007).

Finally, in applying the HC BRidge ${ }^{\mathrm{TM}}$ methodology the researchers were able to indicate some degree of strategic alignment, but definite gaps that were not previously evident were also highlighted. It is therefore important to note that these gaps should be filled in order to strategically contribute towards the bottom line of the company. The importance of strategic reports to ensure a seat at the board table (Darien, 2005) was also highlighted.

\section{Limitations}

- The nature of qualitative research makes replication of the study difficult. Losey et al. (2005) conclude that other organisations cannot just copy this framework and hope for the same results. Instead, they will have to differentiate. This implies that the same process might be followed but different answers will lead to different initiatives and obviously result in different measures and strategic alignment.

- It is also important to remember that the entire HR function should be managed as an integrated whole. A one-sided view might have been created as a result of the compilation of the focus groups and interviews so that they included only recruiters or employees related to the recruitment function.

- Another possible limitation of the focus groups may be that participants filtered their answers according to what they believed the researcher wanted to hear (Bowen, 2005). However, this was hopefully reduced through the verification process during the individual interviews.

\section{Conclusion}

A possible avenue for future research is the development of actual strategic recruitment measures. This will close the loop and conceptualise the value of the recruitment function in the organisation.

In conclusion, the HC BRidge ${ }^{\mathrm{TM}}$ methodology could indicate that the recruitment function has evolved over the last couple of years to include some strategic alignment. However, a considerable effort is still required to ensure complete strategic alignment and to develop (integrate) related metrics to prove the true value added. The HC BRidge ${ }^{\mathrm{TM}}$ framework and methodology can play a key role in achieving this goal.

\section{REFERENCES}

Armstrong, G. (2005). Differentiation through people - how can HR move beyond business partner? In M. Losey, S. Meisinger \& D. Ulrich (Eds.), The future of human resource management, (pp. 86-92). New Jersey: John Wiley \& Sons.

Becker, B.E., Huselid, M.A., \& Beatty, R.W. (2009). The differentiated workforce: Transforming talent into strategic impact. Boston: Harvard Business School Press.

Becker, B.E., Huselid, M.A., \& Ulrich, D. (2001). The HR scorecard: Linking people, strategy, and performance. Boston: Harvard Business School Press.

Bogdan, R.C., \& Biklen, S.K. (1998). Qualitative research in education: An introduction to theory and methods. Needham Heights: Allyn \& Bacon.

Boudreau, J.W., Dunford, B.B., \& Ramstad, P.M. (2000). The human capital "impact" on e-business: The case of Encyclopedia Britannica online. Cornell University: School of Industrial and Labour Relations. Retrieved May 15, 2006, from http:// www.ilr.cornell.edu.depts/CAHRS/

Boudreau, J.W., \& Ramstad, P.M. (2004). Beyond cost-per-hire and time to fill: Supply-chain measurement for staffing. Retrieved May 15, 2006, from http://www.marshall.usc.edu/ceo

Boudreau, J.W, \& Ramstad, P.M. (2007). Beyond HR: The new science of human capital. Boston: Harvard Business School Publishing Corporation.

Bowen, G.A. (2005). Preparing a qualitative research-based dissertation: Lessons learned. The Qualitative Report, 10, 208-222.

Christensen, R. (2006). Roadmap to strategic HR: Turning a great idea into a business reality. New York: Amacom.

Darien, S. (2005). Not just any seat at the table. In M. Losey, S. Meisinger \& D. Ulrich (Eds.), The future of human resource management (pp. 119-133). New Jersey: John Wiley \& Sons.

Davidson, L. (1998). Measure what you bring to the bottom line. Workforce, $77,34-40$ 
Dostal, E., Cloete, A., \& Jaros, G.G. (2005). Biomatrix: A systems approach to organisational and societal change. (3rd edn.). Cape Town: Imaging Data Solutions.

Duggan, B. (2004). Strategic recruitment and retention: Competitive advantage and return on investment. Retrieved July 30, 2008, from www.marathonhrcg.com/pdfs/strategic $\% 20$ Recruitment $\% 20$ and $\% 20 \%$ retention.pdf

Ellig, B. (2005). What distinguishes the outstanding HR executives from the others. In M. Losey, S. Meisinger \& D Ulrich (Eds.), The future of human resource management, (pp. 126-133). New Jersey: John Wiley \& Sons.

Fitz-enz, J. (1987). How to measure human resources management. Bukit Batok: Datagraphics.

Fitz-enz, J., \& Davison, B. (2002). How to measure human resource management. (3rd edn.). Maidenhead: McGraw-Hill.

Flamholtz, E.G. (2005). Human resource accounting, human capital management, and the bottom line. In M. Losey, S. Meisinger \& D. Ulrich (Eds.), The future of human resource management, (pp. 268-277). New Jersey: John Wiley \& Sons.

Grbich, C. (2007). Qualitative data analysis: An introduction. Thousands Oaks: Sage Publications.

Hansen, F. (2004). The move to meaningful metrics. Retrieved March 16, 2006, from http://www.workforce.com/archive/ article/24/19/57.php?ht=recruitment\%20measures

Heraty, N., \& Morley, M. (1998). In search of good fit: Policy and practice in recruitment and selection in Ireland. Journal of Management Development, 17, 662-685.

Huselid, M.A., \& Becker, B.E. (2005). Improving human resources' analytical literacy: Lessons from Moneyball. In M. Losey, S. Meisinger \& D. Ulrich (Eds.), The future of human resource management, (pp. 400-407). New Jersey: John Wiley \& Sons.

Huselid, M.A., Becker, B.E., \& Beatty, R.W. (2005). The workforce scorecard: Managing human capital to execute strategy. Boston: Harvard Business School Press.

Kitzinger, J. (1995). Qualitative research: Introducing focus groups. British Medical Journal, 311, 299-302.

Losey, M., Meisinger, S., \& Ulrich, D. (Eds.) (2005). The future of human resource management. New Jersey: John Wiley \& Sons.
Mayer, J. (2008). Beat the fear, shift contexts to achieve organisational success. HR Future, 5, 24-25.

Millick, S. (2007). Sourcing and recruiting: Trends, challenges and insights. Retrieved January 9, 2008, from http://www. tngconsulting.com

Moore, M.L. (2007). Beyond HR: The new science of human capital. Retrieved August 18, 2008, from www.entrepreneur.com/ tradejournals/article/173925293.html

Neill, J. (2006). Analysis of professional literature class 6: Qualitative research. Retrieved May 29, 2008, from http://wilderdom. com/OEcourses/PROFLIT/Class6Qualitative1.htm

Roberts, A. (1994). Integrating strategy with performance measures. Management Development Review, 7, 13-15.

Rowald, J., \& Mönninghoff, M. (2005). Strategic human resource utility analysis. Journal of Human Resource Costing and Accounting, 9, 10-25.

Saunders, M., Lewis, P., \& Thornhill, A (2003). Research methods for business students. (3rd edn.). New York: Pearson Education.

Smith, M., \& Graves, C. (2002). Re-engineering recruitment to the accounting profession. Managerial Auditing Journal, 17, 117-121.

Terre Blanche, M., \& Durrheim, K. (1999). Research in practice. Cape Town: University of Cape Town Press.

Thomas, D.R. (2003). A general inductive approach for qualitative data analysis. Auckland: School of Population Health.

Van Schalkwijk, O. (2008). Laws of attraction - magnetise your company. HR Future, 3, 12-13.

Weston, C., Gandell, T., Beauchamp, J., McAlpine, C., Wiseman, C., \& Beaucamp, C. (2001). Analysing interview data: The development and evolution of a coding system. Qualitative Sociology, 24, 381-400.

Willig, C. (2003). Introducing qualitative research in psychology. Philadelphia: Open University Press.

Yeung, A. (2005). Becoming business partners in Chinese firms: Challenges and opportunities. In M. Losey, S. Meisinger \& D. Ulrich, (Eds.), The future of human resource management, (pp. 400-407). New Jersey: JohHn Wiley \& Sons. 